\title{
Observations of Reactive Gaseous Mercury in the Free Troposphere at the Mount Bachelor Observatory
}

\section{Citation}

Swartzendruber, Philip C., Daniel A. Jaffe, E. M. Prestbo, P. Weiss-Penzias, Noelle E. Selin, Rokjin Park, Daniel J. Jacob, Sarah Strode, and Lyatt Jaegle. 2006. Observations of reactive gaseous mercury in the free troposphere at the Mount Bachelor Observatory. Journal of Geophysical Research 111: D24301.

\section{Published Version}

doi:10.1029/2006JD007415

\section{Permanent link}

http://nrs.harvard.edu/urn-3:HUL.InstRepos:3743673

\section{Terms of Use}

This article was downloaded from Harvard University's DASH repository, and is made available under the terms and conditions applicable to Other Posted Material, as set forth at http:// nrs.harvard.edu/urn-3:HUL.InstRepos:dash.current.terms-of-use\#LAA

\section{Share Your Story}

The Harvard community has made this article openly available.

Please share how this access benefits you. Submit a story.

Accessibility 


\title{
Observations of reactive gaseous mercury in the free troposphere at the Mount Bachelor Observatory
}

\author{
P. C. Swartzendruber, ${ }^{1,2}$ D. A. Jaffe, ${ }^{1,2}$ E. M. Prestbo, ${ }^{3}$ P. Weiss-Penzias, ${ }^{2}$ \\ N. E. Selin, ${ }^{4}$ R. Park, ${ }^{4}$ D. J. Jacob,${ }^{4}$ S. Strode,${ }^{1}$ and L. Jaeglé ${ }^{1}$ \\ Received 17 April 2006; revised 25 July 2006; accepted 18 August 2006; published 16 December 2006.
}

[1] We measured gaseous elemental mercury (GEM), particulate mercury (PHg), and reactive gaseous mercury (RGM), along with $\mathrm{CO}$, ozone, and aerosol scatter at the Mount Bachelor Observatory (2.7 km above sea level), Oregon, from May to August 2005. The mean mercury concentrations (at standard conditions) were $1.54 \mathrm{ng} / \mathrm{m}^{3}$ (GEM), $5.2 \mathrm{pg} / \mathrm{m}^{3}$ (PHg), and $43 \mathrm{pg} / \mathrm{m}^{3}$ (RGM). RGM enhancements, up to $600 \mathrm{pg} / \mathrm{m}^{3}$, occurred at night and were linked to a diurnal pattern of upslope and downslope flows that mixed in boundary layer air during the day and free tropospheric air at night. During the night, RGM was inversely correlated $(\mathrm{P}<0.0001)$ with $\mathrm{CO}(\mathrm{r}=-0.36)$, GEM $(\mathrm{r}=-0.73)$, and $\mathrm{H}_{2} \mathrm{O}(\mathrm{r}=-0.44)$, was positively correlated with ozone $(\mathrm{r}=0.38)$, and could not be linked to recent anthropogenic emissions from local sources or long-range transport. Principal component analysis and a composite of change in RGM versus change in GEM during RGM enhancements indicate that a nearly quantitative shift in speciation is associated with increases in ozone and decreases in water vapor and $\mathrm{CO}$. This argues that high concentrations of RGM are present in the free troposphere because of in situ oxidation of GEM to RGM. A global chemical transport model reproduces the RGM mean and diurnal pattern but underestimates the magnitude of the largest observed enhancements. Since the only modeled, in situ RGM production mechanisms are oxidation of GEM by ozone and $\mathrm{OH}$, this implies that there are faster reaction rates or additional RGM production mechanisms in the free troposphere.

Citation: Swartzendruber, P. C., D. A. Jaffe, E. M. Prestbo, P. Weiss-Penzias, N. E. Selin, R. Park, D. J. Jacob, S. Strode, and L. Jaeglé (2006), Observations of reactive gaseous mercury in the free troposphere at the Mount Bachelor Observatory,

J. Geophys. Res., 111, D24301, doi:10.1029/2006JD007415.

\section{Introduction}

[2] The extent to which oxidized forms of mercury are present in the atmosphere remains a key uncertainty in our understanding of the global cycling of mercury [Schroeder and Munthe, 1998; Stratton et al., 2001]. Knowledge of the speciation of airborne mercury is important because of the radically different behaviors of each species and the resulting sensitivity on deposition fluxes [Shia et al., 1999; Bergan and Rodhe, 2001]. Reactive gaseous mercury (RGM) is an operationally defined fraction of atmospheric mercury based on its collection by a $\mathrm{KCl}$ denuder [Landis et al., 2002]. It is believed to be a divalent compound such as $\mathrm{HgCl}_{2}$ or $\mathrm{HgO}$, which, unlike gaseous elemental mercury (GEM), is rapidly deposited to particles and surfaces and is

\footnotetext{
${ }^{1}$ Department of Atmospheric Sciences, University of Washington, Seattle, Washington, USA.

${ }^{2}$ Interdisciplinary Arts and Sciences, University of Washington-Bothell, Bothell, Washington, USA.

${ }^{3}$ Frontier Geosciences, Seattle, Washington, USA.

${ }^{4}$ Department of Earth and Planetary Sciences, Harvard University, Cambridge, Massachusetts, USA.

Copyright 2006 by the American Geophysical Union. 0148-0227/06/2006JD007415\$09.00
}

efficiently sequestered by rain and cloud droplets. Consequently, the lifetime of RGM in the atmosphere is believed to be substantially shorter than the global mean residence time of GEM (6-24 months). Mercury which is bound to particles $(\mathrm{PHg})$ is constrained to the lifetime of the carrier particle, typically less than 10 days, which is also considerably shorter than the lifetime of GEM.

[3] Atmospheric mercury is believed to be predominantly GEM. Natural emissions and reemissions are also believed to be almost entirely GEM [Mason and Sheu, 2002; Gustin et al., 2000]. Anthropogenic emissions to the atmosphere are dominated by GEM $(60-70 \%)$, with the balance being RGM and PHg [Carpi, 1997; Pacyna et al., 2006; Streets et al., 2005]. It has generally been assumed that there are negligible concentrations of reactive species distant from anthropogenic sources. The validity of this assumption has been challenged by recent studies in the polar regions [Lindberg et al., 2002; Steffen et al., 2002; Berg et al., 2003; Ebinghaus et al., 2002; Sprovieri et al., 2002; Temme et al., 2003] and over the open ocean [Laurier et al., 2003; Sprovieri et al., 2003] that have shown that RGM can be produced in remote regions from the oxidation of GEM.

[4] Low-altitude ground-based studies in the middle latitudes have supported the assumption that little RGM 


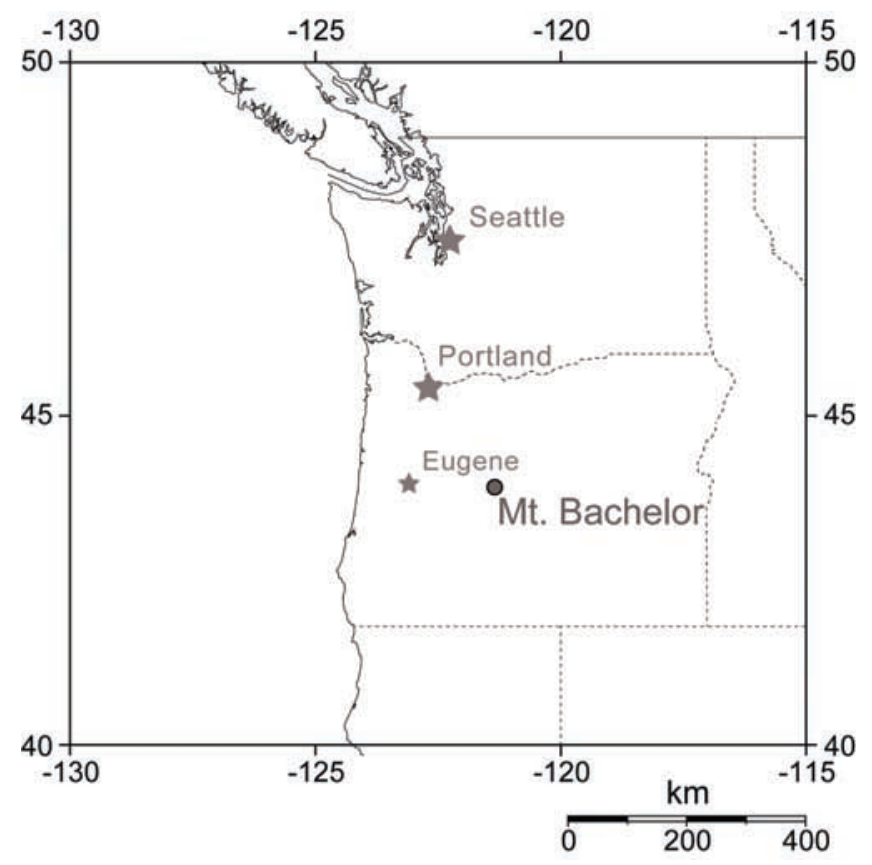

Figure 1. Location of the Mount Bachelor Observatory in the Pacific Northwest of the United States.

or $\mathrm{PHg}$ is present distant from sources. Most studies [e.g., Sheu and Mason, 2001; Landis et al., 2002; Malcolm et al., 2003; Weiss-Penzias et al., 2003; Poissant et al., 2005] report that the reactive and particulate fractions are less than $5 \%$ and often less than $2 \%$ of the total airborne mercury $(\mathrm{THg}=\mathrm{GEM}+\mathrm{RGM}+\mathrm{PHg})$.

[5] There have been few studies of mercury in the free troposphere. Several groups have conducted aircraft studies of mercury above the planetary boundary layer, but have generally measured only $\mathrm{THg}$ or have assumed that all of the mercury which was detected was present in the atmosphere as GEM. They found either little or no change in mercury mixing ratios with height [Ebinghaus and Slemr, 2000; Banic et al., 2003] while several others report a slight decrease with height [Brosset, 1987; Kvietkus, 1995; Friedli et al., 2004]. Recent mass spectrometer measurements near the tropopause have discovered mercury associated with particles and have suggested that large fraction of the mercury in the lower stratosphere may be in the particulate fraction [Murphy et al., 2006]. Preliminary reports from measurements at the Mauna Loa Observatory and airborne measurements in Florida [Landis et al., 2005] have suggested that there are elevated levels of RGM and PHg in the free troposphere.

[6] In the Pacific Northwest, Weiss-Penzias et al. [2003] studied mercury speciation at the Cheeka Peak Observatory near the coast of Washington State and reported very low levels of RGM and PHg $(<3 \%$ of the total airborne mercury). More recently, Jaffe et al. [2005] report on observations of Asian outflow at Okinawa, Japan, and the detection of the long-range transport (LRT) of Asian THg to the Mount Bachelor Observatory (MBO) in Oregon. In the spring of 2004, they observed well correlated enhancements of $\mathrm{THg}$ and $\mathrm{CO}$ which were linked to Asian anthropogenic emissions. Subsequently, Weiss-Penzias et al. [2006] describe observations from the site in greater detail and focus on the identification of free tropospheric air, LRT of pollution from Asia, and other air mass types.

[7] In this paper, we examine the speciation of $\mathrm{Hg}$ in the free troposphere at the Mount Bachelor Observatory and aim to improve our understanding of its chemistry by posing the following questions:

[8] 1. What are the concentrations and distributions of the three major mercury species (GEM, RGM, PHg) in the free troposphere?

[9] 2. If elevated concentrations of RGM or $\mathrm{PHg}$ are observed, can they be linked to anthropogenic emissions, from either local sources or long-range transport?

[10] 3. Is there any evidence for the in situ production of RGM and if so, what mechanisms are likely responsible?

[11] 4. How do observed concentrations and dominant reactions compare to our current understanding (i.e., as modeled)?

\section{Methodology \\ 2.1. Site Description}

[12] All measurements in this study were made at the Mount Bachelor Observatory (hereafter MBO), Oregon (43.98N 121.69W, $2.7 \mathrm{~km}$ above sea level (asl)). The site location is shown in Figure 1. The site was established in 2004 and has been previously described by Jaffe et al. [2005] and Weiss-Penzias et al. [2006]. The summit sits approximately $1.4 \mathrm{~km}$ above the surrounding terrain and receives predominantly westerly winds. There are no emission points at the summit or in the surrounding area with the exception of the Mount Bachelor snow grooming equipment, but these can be easily identified from sharp enhancements in $\mathrm{CO}, \mathrm{NO}_{x}$, and aerosol scatter. The nearest source of anthropogenic pollution is the city of Bend which is approximately $30 \mathrm{~km}$ to the east but is only rarely upwind. MBO frequently samples free tropospheric air and has detected the long-range transport of anthropogenic pollutants such as $\mathrm{CO}, \mathrm{THg}$, and aerosols from eastern Asia [Jaffe et al., 2005; Weiss-Penzias et al., 2006]. The predominant free tropospheric influence at MBO was identified by a comparison to mean water vapor profiles from rawinsondes launched from Medford and Salem, Oregon [Weiss-Penzias et al., 2006].

\subsection{Atmospheric Chemical Measurements}

[13] Measurements made in 2005 were real time or near real time and included $\mathrm{Hg}$ (GEM, RGM, PHg), CO, ozone, aerosol scatter $\left(\sigma_{s p}\right)$, water vapor, $\mathrm{CO}_{2}, \mathrm{NOx}$, condensation nuclei, and basic meteorology. Mercury measurements are described below and the remaining measurements are described in greater detail by Weiss-Penzias et al. [2006] and Jaffe et al. [2005]. Ozone was measured with a Dasibi 1008 RS which uses a standard UV absorption method. CO measurements were made with a Thermo Electron Corporation nondispersive infrared instrument (NDIR). Dry aerosol light scattering at $535 \mathrm{~nm}\left(\sigma_{s p}\right)$ was made with a Radiance Research nephelometer. Water vapor was calculated from temperature and relative humidity sensors (Campbell Scientific HMP 45C) and directly from a Licor 6262 (which also measures $\mathrm{CO}_{2}$ ). 


\subsection{Mercury Measurement}

[14] Gaseous elemental mercury (GEM) was measured with a Tekran 2537A on continuous, 5-minute cycles by preconcentration on alternating gold cartridges, thermal desorption, and quantification by cold vapor atomic fluorescence spectroscopy (CVAFS). The mercury speciation measurements were made with the Tekran 1130 and 1135 modules which are described by Landis et al. [2002]. RGM and $\mathrm{PHg}$ are operationally defined fractions of mercury based on their selective capture when passing through a $\mathrm{KCl}$ coated annular denuder and a quartz fiber filter, respectively. We assume that RGM is primarily gaseous $\mathrm{Hg}$ (II) compounds. After the completion of a speciation collection period (3 hours in this work), the RGM and $\mathrm{PHg}$ fractions are quantified by adding an excess flow of mercury-free air to the tip of the sampling train, and then sequentially heating the pyrolyzer, quartz fiber filter, and denuder. The adsorbed $\mathrm{Hg}$ fractions are either reduced to GEM immediately upon heating or are volatilized and passed to the downstream pyrolyzer where they are reduced to GEM and quantified by the 2537A as GEM.

\subsection{Mercury Calibration and Quality Assurance}

[15] An internal GEM permeation source in the 2537A was cross-referenced to manual injections before and after deployment to the field. A Tekran 2505 vapor source and precision microsyringe (Hamilton) were used to inject known amounts of gaseous mercury into a supply of zero air. Before deployment to the field, the measured permeation rate agreed with the rate certified by the manufacturer to better than $8 \%$. After the end of the campaign, the permeation rate was again cross-referenced and was found to agree with the rate measured at the beginning of the campaign to better than $2 \%$. While in the field, the Tekran $2537 \mathrm{~A}$ was automatically calibrated to the internal permeation source every 40 hours. The relative standard deviation of these calibrations was less than $2 \%$.

[16] The GEM measurements have an estimated method detection limit of $0.1 \mathrm{ng} / \mathrm{m}^{3}$ (for a 5-minute collection time), a mean hourly precision of better than $2 \%(1-\sigma)$, and an accuracy of $15 \%$. This speciation method has shown good precision in field tests and has quantitatively measured an RGM proxy $\left(\mathrm{HgCl}_{2}\right)$ in the laboratory [Landis et al., 2002]. To date, however, there have been no reports on the sensitivity of this method to other potential gaseous $\mathrm{Hg}$ (II) or $\mathrm{Hg}(\mathrm{I})$ species.

[17] The denuder and regenerable filter pack (RFP) were replaced approximately every 2-3 weeks with a freshly cleaned and recoated set. Both the denuder and RFP were cleaned by soaking in a $10 \% \mathrm{HNO}_{3}$ (trace metal grade) solution for 24 hours followed by rinsing with double deionized (DDI) water $(>17.6 \mathrm{M} \Omega \mathrm{cm})$ followed by soaking for 24 hours in DDI. After cleaning, the denuder was recoated with a $\mathrm{KCl}$ solution and a new quartz fiber filter was installed in the RFP.

\subsection{High-Volume Inlet}

[18] Because of the extreme meteorological conditions often present at MBO (e.g., heavy riming, winds in excess of $20 \mathrm{~m} / \mathrm{s}$, and temperatures $<0^{\circ} \mathrm{C}$ ) the $1130-1135$ unit was installed inside the building at the summit, and a highvolume tube was added to bring air to the $1130 / 5$ sample train. The high-volume system was designed to have a cut point of $2.5 \mu \mathrm{m}$ in $20 \mathrm{~m} / \mathrm{s}$ cross winds with a Reynolds number along its length of $<1800$ in order to allow laminar flow to subsequently develop. A $2.5 \mu \mathrm{m}$ cyclone particle separator sampled from the center of the high-volume tube about $30 \mathrm{~cm}$ from the tip. The cyclone then connected to the zero-air manifold on the end of the sampling train. The high-volume tube and cyclone (URG Corporation) were Teflon coated and heated to $40^{\circ} \mathrm{C}$. The flow through the high-volume system was about $120 \mathrm{lpm}$.

\subsection{Principal Component Analysis}

[19] The method of principal component analysis (PCA) is also commonly referred to as Factor Analysis or Empirical Orthogonal Function (EOF) analysis. PCA reduces a two-dimensional set of data to a series of functions along each of the dimensions. These functions (or principal components, PCs) are orthogonal structures which most efficiently reproduce the variance contained in the data set. The statistical uniqueness of each principal component relative to one another can be estimated on the basis of the autocorrelation and a hypothetical red noise spectrum [North et al., 1982; Bretherton et al., 1999]. For this work, we use the $95 \%$ confidence limits for the uniqueness of the PCs as described by North et al. [1982], which is based upon the number of degrees of freedom following Leith [1973]. A factor having statistical uniqueness, does not, by that fact alone, guarantee that it is physically meaningful. Real world factors, e.g., marine air versus continental air, may have properties which are not orthogonal to each other. Or, all components may be rotated in phase space simply for mathematical efficiency. Therefore assigning physical significance to the results of PCA should be done conservatively [von Storch and Zwiers, 1999].

\subsection{Chemical Model}

[20] This paper uses results from the first application of the GEOS-Chem model to global mercury which is described by Selin et al. [2006] and S. Strode et al. (Global simulation of air-sea exchange of mercury, submitted to Global Biogeochemical Cycles, 2006, hereinafter referred to as Strode et al., submitted manuscript, 2006). The GEOSChem model has been extensively evaluated along the West Coast with respect to observations and transport of ozone, CO, and other chemicals [Jaeglé et al., 2003; Hudman et al., 2004; Liang et al., 2004; Goldstein et al., 2004; Heald et al., 2006].

[21] GEOS-Chem is a global chemical transport (CTM) model driven by assimilated meteorological fields from the Goddard Earth Observing System (GEOS) Global Modeling and Assimilation Office [Bey et al., 2001]. The chemical species are calculated at a resolution of $4^{\circ}$ latitude by $5^{\circ}$ longitude and at 30 vertical levels. Mercury emissions data were taken from the Pacyna et al. [2006] inventory of 2000 emissions. The modeled mercury reactions include oxidation of GEM to RGM by OH with the rate of Sommar et al. [2001] $\left(k=7 \times 10^{-14} \mathrm{~cm}^{3}\right.$ molec. $\left.{ }^{-1} \mathrm{~s}^{-1}\right)$ and the oxidation of GEM to RGM by ozone with the rate of Hall [1995] $\left(k=3 \times 10^{-20} \mathrm{~cm}^{3}\right.$ molec. $\left.{ }^{-1} \mathrm{~s}^{-1}\right)$. Note that the oxidation of GEM by halogens is not included at this time. Also included is the aqueous photochemical reduction of $\mathrm{Hg}$ (II) which is described by Selin et al. [2006] and an ocean 


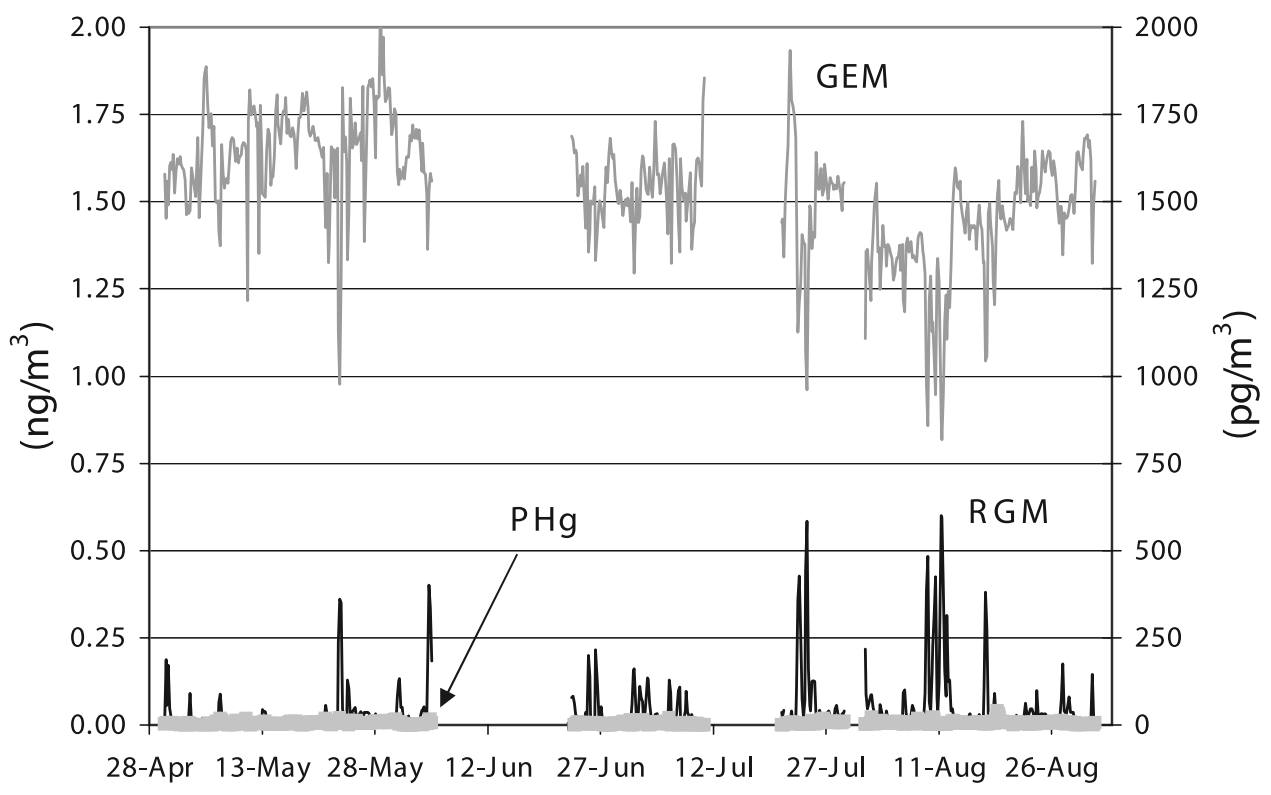

Figure 2. Time series of GEM, RGM, and PHg from 30 April to 30 August 2005. Note that there was very little PHg observed (approximately 4\% relative to RGM during the highest quartile).

model which is described by Strode et al. (submitted manuscript, 2006).

\section{Results and Discussion}

\subsection{Aggregate Data}

[22] The data were collected from 30 April to 31 August 2005 and have been compiled into 3-hour means which correspond to the speciation collection period. The data recovery for this period of 124 days is $53 \%$ because the system is in speciation analysis mode every fourth hour and there were two extended periods with mechanical failures (30 days total). The mean concentrations for periods when all $\mathrm{Hg}$ values were available $(\mathrm{n}=527)$ and their respective standard deviations $(1-\sigma)$ for GEM, PHg, and RGM are $1.54(0.176) \mathrm{ng} / \mathrm{m}^{3}, 5.2(4.4) \mathrm{pg} / \mathrm{m}^{3}$, and $43(82) \mathrm{pg} / \mathrm{m}^{3}$ respectively. A complete time series of the three mercury species is plotted in Figure 2.

[23] Table 1 summarizes the concentrations during all available periods and the nighttime only. PHg and RGM ranged from below the estimated detection limit to 40 and $600 \mathrm{pg} / \mathrm{m}^{3}$, respectively. GEM concentrations ranged from 0.82 to $2.08 \mathrm{ng} / \mathrm{m}^{3}$ and had a mean $\left(1.54 \mathrm{ng} / \mathrm{m}^{3}\right)$ and median $\left(1.55 \mathrm{ng} / \mathrm{m}^{3}\right)$ which are in good agreement with lowelevation surface measurements [Ebinghaus et al., 1999; Weiss-Penzias et al., 2003; Poissant et al., 2005] and modeled values for remote regions in the middle latitudes [Seigneur et al., 2004]. This is consistent with the findings of Banic et al. [2003] that show little or no vertical gradient of GEM in the lower troposphere.

\subsection{Diurnal Pattern}

[24] We observed RGM enhancements of $>50 \mathrm{pg} / \mathrm{m}^{3}$ during about one third of the nights. During these periods, PHg enhancements were also observed, but they averaged only $4.1 \%$ of the corresponding RGM enhancement. These enhancements were generally characterized by simultaneous shifts in water vapor, ozone, and GEM. Figure 3 shows an example of this pattern as observed on 23 May 2005 (day 143). Using 5-minute average data, during the beginning and end of these periods, the changes in water vapor, GEM, and ozone were generally well correlated. At the beginning of the event shown in Figure 3, water vapor and ozone were strongly anticorrelated $\left(\mathrm{r}^{2}=0.93\right)$. Unfortunately, GEM data were not available during the onset of this event

Table 1. Summary of Observed Data ${ }^{a}$

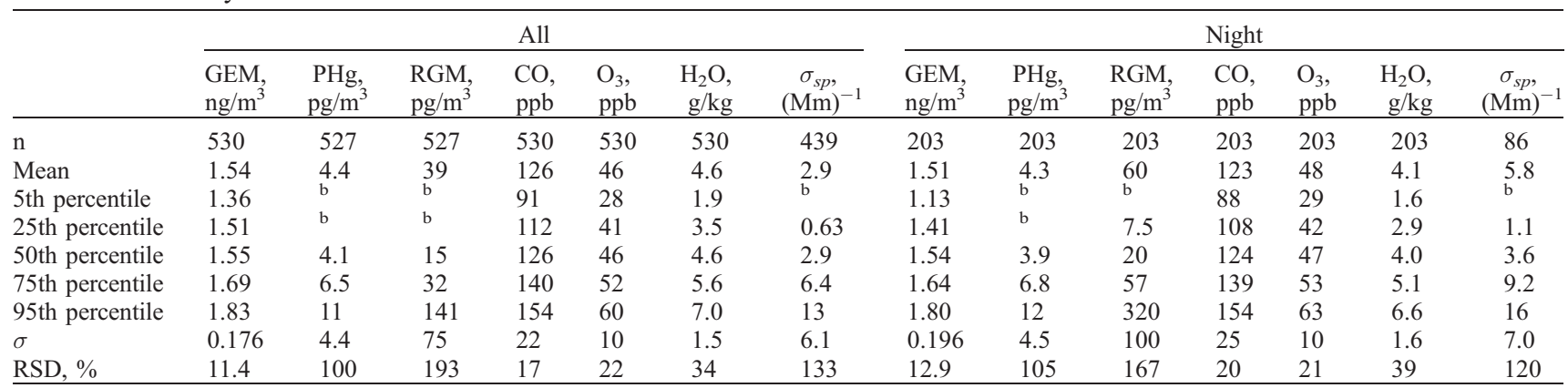

${ }^{\mathrm{a}} \mathrm{Here}, \sigma$ is the standard deviation, and RSD is the relative standard deviation; $\mathrm{n}$ is the number of 3-hour periods.

${ }^{\mathrm{b}}$ Below estimated detection limit. 


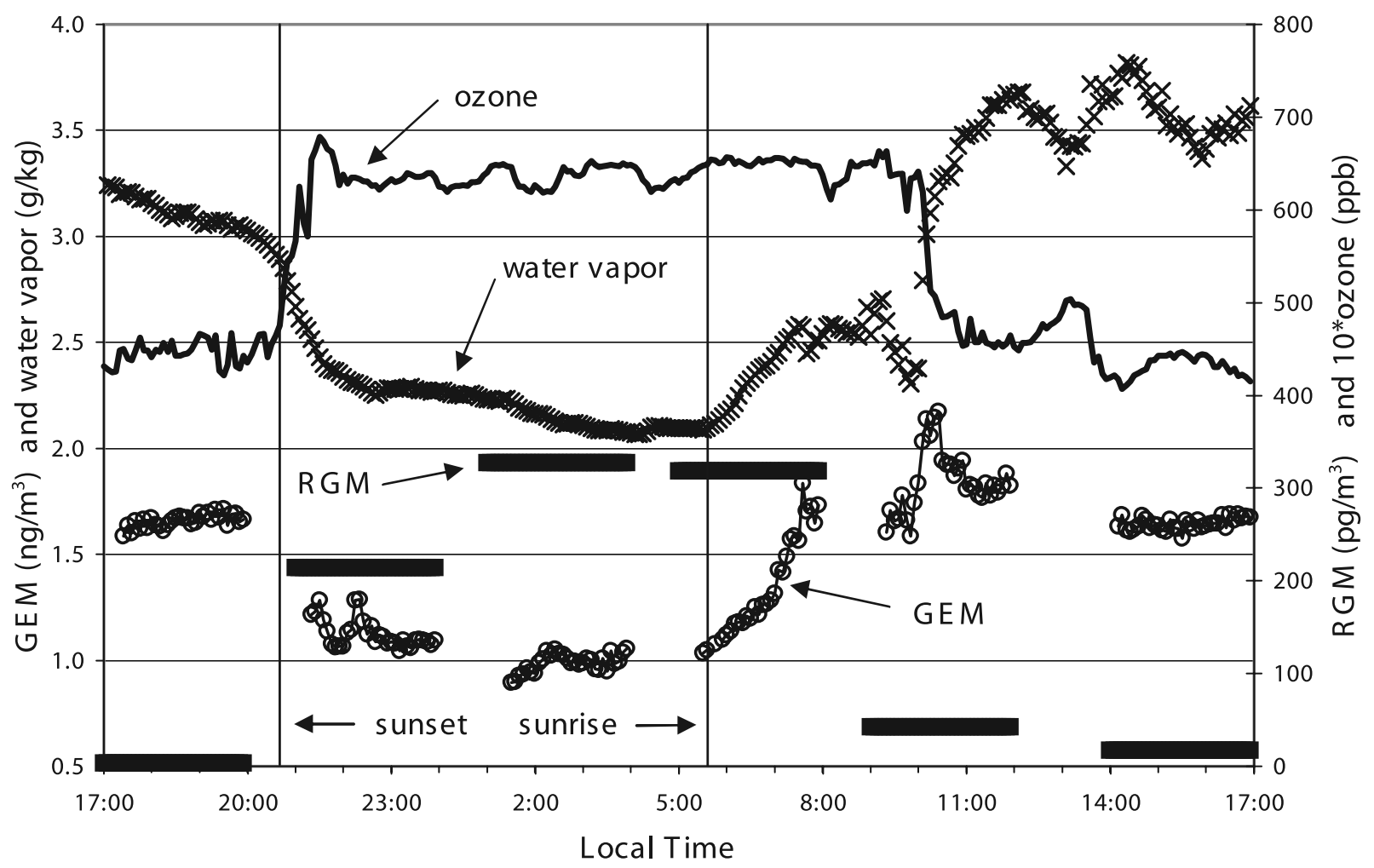

Figure 3. Example of nighttime air mass change on 23 May 2005 (day 143).

because the $\mathrm{Hg}$ instrument was in the $\mathrm{PHg}$ and RGM analysis cycle, but the change in GEM can be inferred from the values before and after the transition.

[25] The end of the episode has a more complex pattern through which all of the concentrations returned to typical daytime values. Soon after sunrise, water vapor and GEM were well correlated and began to increase while the ozone remained elevated. GEM continued to increase and exceeded the typical daytime value, but returned within about an hour. Ozone remained elevated during the increase of GEM and water vapor, while RGM dropped to negligible levels. The spike in GEM at the end of the nighttime enhancement could be caused by the reemission of previously deposited mercury driven by sunlight and/or changes in water vapor which is advected to the summit by upslope flow. Also, the changes in chemical concentrations at the end of the enhancements, in several instances, were well correlated to changes in the wind speed and direction. This diurnal pattern can also be seen in the mean hourly RGM concentrations depicted in Figure 4.

[26] The observed diurnal cycle of water vapor is similar to that observed by Weiss-Penzias et al. [2006] in the spring of 2004 and is evidence that the MBO daytime observations in the summer of 2005 include some degree of boundary layer influence. Following Weiss-Penzias et al. [2006], we interpret this pattern as being driven primarily by anabatic (upslope) winds mixing in boundary layer air during the day, and katabatic (downslope) winds bringing down free tropospheric air at night. This diurnal pattern in RGM concentrations is the opposite of that observed at lowelevation surface stations [Lindberg and Stratton, 1998; Sheu and Mason, 2001; Laurier et al., 2003; Hedgecock et al., 2003; Poissant et al., 2005]. Because the nighttime values are more representative of free tropospheric air, further analysis of only the nighttime data (section 3.4) will be performed to focus on the behavior of mercury in the free troposphere.

\subsection{Principal Component Analysis}

3.3.1. Evaluation of Analytical Significance

[27] Principal component analysis (PCA) without rotation was performed on all of the 3-hour data $(n=495)$ when all

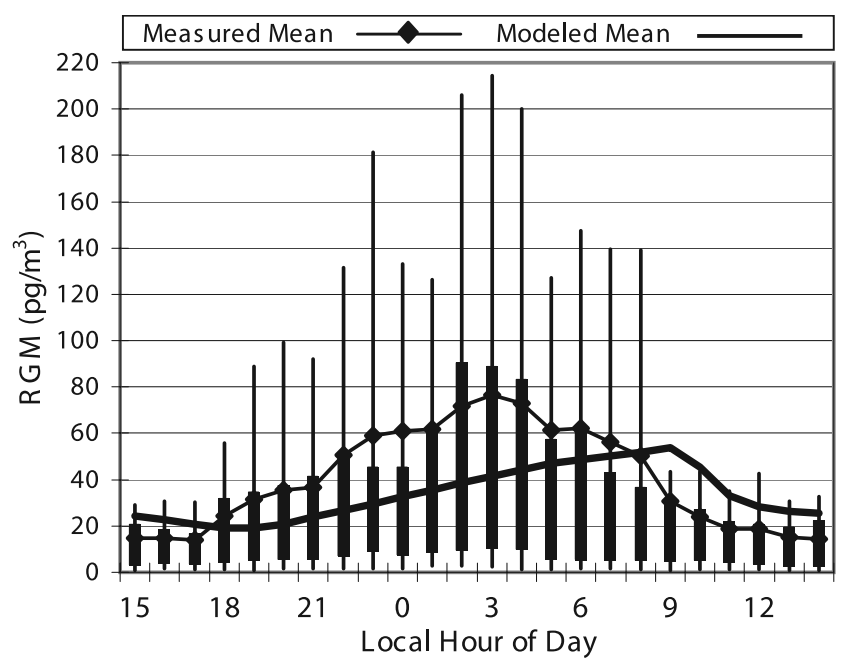

Figure 4. Mean observed diurnal RGM pattern. The boxes show 25th and 75th percentiles, and whiskers show 10th and 90th percentiles, along with observed and GEOSChem-predicted mean diurnal concentration. 




Figure 5. First two eigenvectors (normalized) showing direction and magnitude of variance within each eigenvector.

of the following parameters were available: GEM, RGM, ozone, water vapor, and CO. A normal quantile plot was generated for each parameter to check for normal distributions. All were found to be reasonably well represented by a normal distribution with the exception of the RGM data which were lognormal. The RGM data were therefore log transformed for the principal component analysis.

[28] Following North et al. [1982], principal components are considered statistically unique if their 95\% confidence limits do not overlap those of the adjacent components and the eigenvalues are greater than the expected value of one. For this data, only the first two principal components are statistically unique from each other and the remaining components.

[29] PCA was performed on the data in three variations in order to examine the robustness of the components. For the base case, all available data were used. In the second variation, no RGM data were used, and in the third variation, extreme values (defined as 1.5 times the interquartile range) of all parameters were discarded. The pattern obtained in the components of the three variations were nearly identical except for small shifts in the magnitude of the ozone and $\mathrm{CO}$ terms. We therefore believe the PCA to be robust with regard to the first two principal components.

[30] For the base case, the first two components explain $47 \%$ and $27 \%$, respectively, of the total variance of the data set and the balance of the variance is contained in the nonunique remaining three components which will not be discussed further.

\subsubsection{Properties of the Components}

[31] The first two eigenvectors (which correspond to the first two PCs) are plotted in Figure 5. In this figure, the magnitude of the value indicates the strength of the variance explained for each parameter and the signs indicate the direction of change relative to the other parameters in the same eigenvector. The first eigenvector is characterized by a strong anticorrelation of GEM and water vapor with both RGM and ozone. CO is only weakly related to this component but does vary with GEM and water vapor, and is opposite to RGM and ozone. The second principal component shows a positive relationship between $\mathrm{CO}$, ozone and GEM and an inverse relationship to water vapor.

[32] The amount of variance $\left(\mathrm{r}^{2}\right)$ of each chemical which is explained by the first two principal components is plotted in Figure 6. The first component explains $79 \%$ of the variance of RGM, while the second component explains less than $1 \%$. Similarly, the second principal component explains about $65 \%$ of the variance of $\mathrm{CO}$, while the first component explains only about $18 \%$.

[33] In the first eigenvector, the decrease in water vapor and increase in ozone is consistent with a free tropospheric influence that is strong during the night. The second eigenvector is consistent with two possible physical influences. The first influence is relatively clean boundary layer or marine air which has higher water vapor and relatively low GEM, CO, and ozone. The second plausible influence is the degree of pollution during and outside of RGM enhancements which is independent of RGM.

\subsection{Nighttime Data}

\subsubsection{Linear Correlation}

[34] On the basis of the observation of a strong diurnal cycle of RGM and water vapor and the analysis of WeissPenzias et al. [2006], the nighttime data are more likely to be representative of free tropospheric air and will now be considered separately. Table 2 shows the Pearson's correlation coefficients for the 3-hour mean nighttime data $(\mathrm{n}=$ 157) for GEM, PHg, RGM, ozone, water vapor, $\mathrm{CO}$, and aerosol scatter $\left(\sigma_{s p}\right)$. Data were available for all of the chemicals except aerosol scatter for 32 additional 3-hour periods. The correlations were also calculated for the more lengthy record which does not include $\sigma_{s p}(\mathrm{n}=189)$, but the correlation coefficients were not significantly different. Values in bold are significant at $\alpha=0.01$. The strongest correlations exist between GEM and RGM ( $\mathrm{r}=-0.73)$, GEM and CO ( $\mathrm{r}=0.54), \mathrm{RGM}$ and water vapor $(\mathrm{r}=-0.44)$, and GEM and water vapor $(0.43)$ which are all significant at $\alpha=0.0001$.

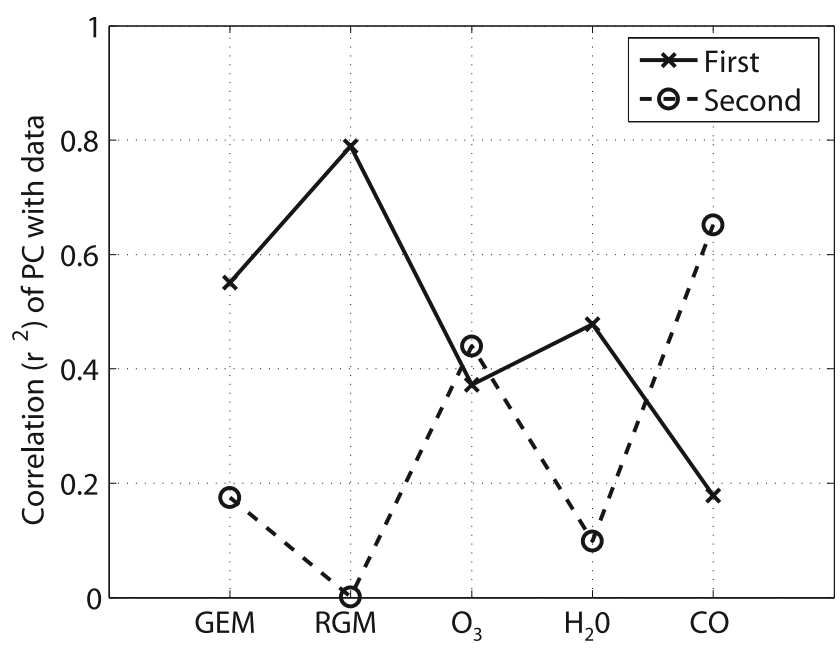

Figure 6. Fraction of the total variance of each chemical that is explained by each of the first two principal components. 
Table 2. Pearson's Correlation Coefficient $r$ for Nighttime Data ${ }^{a}$

\begin{tabular}{|c|c|c|c|c|c|c|}
\hline Correlation $\mathrm{r}$ & GEM & $\mathrm{PHg}$ & RGM & Ozone & $\mathrm{H}_{2} \mathrm{O}$ & $\mathrm{CO}$ \\
\hline $\mathrm{PHg}$ & -0.15 & 1 & & & & \\
\hline RGM & -0.73 & 0.07 & 1 & & & \\
\hline Ozone & -0.20 & 0.31 & 0.38 & 1 & & \\
\hline $\mathrm{H}_{2} \mathrm{O}$ & 0.43 & -0.14 & -0.44 & -0.36 & 1 & \\
\hline $\mathrm{CO}$ & 0.54 & 0.27 & -0.36 & 0.06 & 0.15 & 1 \\
\hline$\sigma_{s p}$ & -0.05 & 0.44 & -0.02 & 0.20 & 0.19 & 0.32 \\
\hline
\end{tabular}

${ }^{\mathrm{a}}$ Correlations significant at $\alpha=0.01$ are indicated in bold.

\subsubsection{Highest and Lowest RGM Quartiles}

[35] The nighttime data were further segregated into quartiles on the basis of the mean nightly RGM concentration in order to characterize RGM-rich air masses and contrast them to RGM-lean air masses. Three-dimensional kinematic back trajectories were calculated for each of the evenings of the highest and lowest RGM quartiles using the NOAA HYSPLIT (R. R. Draxler and G. D. Rolph, HYSPLIT (Hybrid Single-Particle Lagrangian Integrated Trajectory) Model access via NOAA ARL READY Website (http://www.arl.noaa.gov/ready/hysplit4.html), 2003) model and FNL meteorological data. One back trajectory was started at the summit height $(2700 \mathrm{~m}$ asl, which is approximately $1400 \mathrm{~m}$ above ground level in the modeled terrain). All of the trajectories for the highest quartile originated over the middle latitudes of the Pacific Ocean and spent very little time over the North American continent. The trajectories from the lowest quartile spent much more time over land and many originated over the North American continent. At 60 and 120 hours prior to arrival at MBO, the mean heights above ground level for the lowest RGM quartile were $1030 \mathrm{~m}$ and $1360 \mathrm{~m}$, respectively. For the highest RGM quartile, at 60 and 120 hours prior to arrival at $\mathrm{MBO}$, the mean trajectory heights were $2500 \mathrm{~m}$ and $3100 \mathrm{~m}$ above ground level. This indicates that the highest-quartile air masses had origins in the free troposphere, while the lowest quartile trajectories originated almost exclusively from the boundary layer. The highest-RGM-quartile air masses also contained lower GEM, which would be consistent with a slight negative GEM gradient with altitude. The properties of the highest and lowest quartiles are summarized in Table 3 .

\subsection{Sources of RGM}

[36] The poor correlation of RGM with two commonly used tracers for direct anthropogenic pollution, $\mathrm{CO}$ and $\sigma_{s p}$, argues that the RGM observed nightly at MBO was not due to recent anthropogenic pollution from either local sources or from long-range transport. A significant fraction of the atmospheric burden of GEM which is being converted to RGM, however, is of anthropogenic origins [Mason and Sheu, 2002; Seigneur et al., 2004; Streets et al., 2005]. The strongest correlations are the inverse relationships between RGM and GEM, and RGM and water vapor. Principal component analysis also supports these correlations and suggests that this relationship is the dominant influence on the overall data set. The weak correlation of CO to the first principal component also supports the argument that the RGM could not be linked to recent, direct anthropogenic pollution. The first principal component (as can be seen in the recreated $\ln (\mathrm{RGM})$ data and the correlation coefficient) accurately captures the variability of the RGM and is precisely what would be expected from the mixing in of free tropospheric air. The second principal component is dominated by the variance of CO with ozone and GEM and is uncorrelated to RGM. It is plausible that this component reflects relatively clean and moist marine air, or the degree of pollution (GEM, ozone, and CO) of free tropospheric air masses [Jaffe et al., 2005; Weiss-Penzias et al., 2006], which is independent of RGM.

[37] In order to investigate whether the RGM observed was consistent with a conversion of species, $\Delta[\mathrm{GEM}]$ and $\Delta[\mathrm{RGM}]$ values were composited for the largest enhancements and a regression was calculated. For this calculation, it is assumed that the background values (lowest RGM and highest GEM for each enhancement) are an accurate proxy for the RGM rich air before oxidation began. Therefore the $\mathrm{THg}(\mathrm{GEM}+\mathrm{RGM}+\mathrm{PHg})$ in the background and RGM rich air must be equal. For the enhancements observed at $\mathrm{MBO}$, the $\mathrm{PHg}$ comprised an average of $0.4 \%$ of the $\mathrm{THg}$ and is assumed to be negligible for this discussion. Under this assumption, a regression slope of -1 would indicate a

Table 3. Summary of Nighttime Data Segregated by RGM Into Highest and Lowest Quartiles ${ }^{\mathrm{a}}$

\begin{tabular}{|c|c|c|c|c|c|}
\hline & \multirow[b]{2}{*}{ Units } & \multicolumn{2}{|c|}{ Highest Quartile, $\mathrm{n}=52$} & \multicolumn{2}{|c|}{ Lowest Quartile, $\mathrm{n}=49$} \\
\hline & & Mean & $\sigma$ & Mean & $\sigma$ \\
\hline $\mathrm{H}_{2} \mathrm{O}$ & $\mathrm{g} / \mathrm{kg}$ & 3.0 & 1.3 & 4.7 & 1.0 \\
\hline Temperature & C & 5.3 & 5.6 & -1.2 & 3.3 \\
\hline RH & $\%$ & 46 & 29 & 96 & 11 \\
\hline-60 hours $^{b}$ & (m)a.g.l. & 2500 & 740 & 1030 & 680 \\
\hline-120 hours $^{\mathrm{b}}$ & (m)a.g.l. & 3100 & 1300 & 1360 & 930 \\
\hline GEM & $\mathrm{ng} / \mathrm{m}^{3}$ & 1.32 & 0.212 & 1.64 & 0.107 \\
\hline $\mathrm{PHg}$ & $\mathrm{pg} / \mathrm{m}^{3}$ & 5.7 & 5.2 & 2.5 & 3.1 \\
\hline RGM & $\mathrm{pg} / \mathrm{m}^{3}$ & 194 & 154 & 3.4 & 3.0 \\
\hline Ozone & ppbv & 52 & 11 & 38 & 7.7 \\
\hline $\mathrm{CO}$ & ppbv & 116 & 38 & 130 & 20 \\
\hline$\sigma_{s p}$ & $(\mathrm{Mm})^{-1}$ & 4.4 & 8.3 & 1.2 & 2.6 \\
\hline
\end{tabular}

${ }^{\mathrm{a}}$ Here, $\mathrm{n}$ is the number of 3 -hour periods, and $\sigma$ is the standard deviation.

${ }^{\mathrm{b}}$ The height of the back trajectory (m) above ground level at stated hours prior to arrival at MBO. 


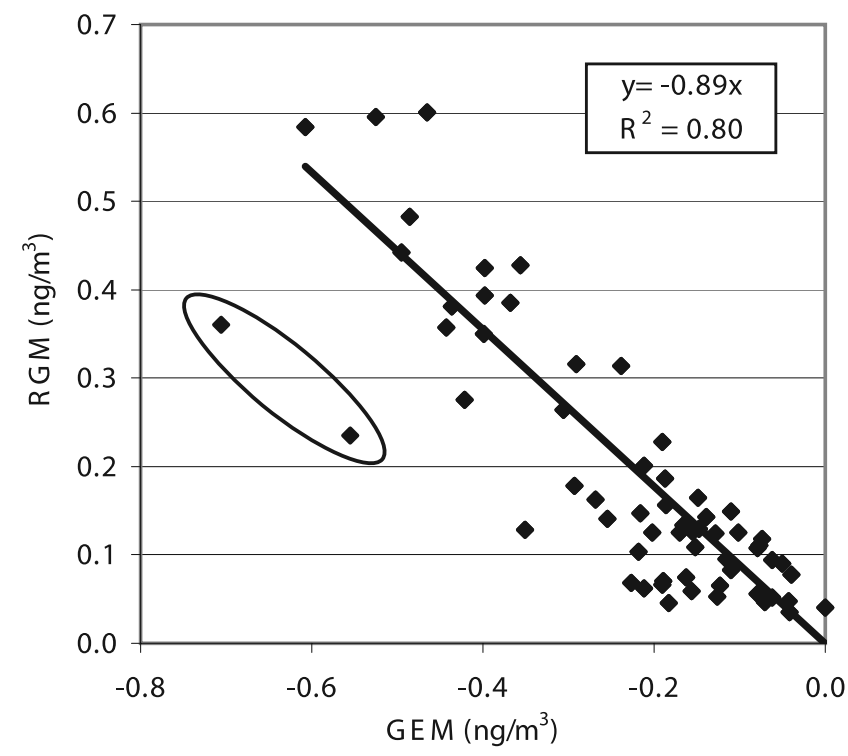

Figure 7. Scatterplot of $\triangle \mathrm{RGM}$ versus $\triangle \mathrm{GEM}$. Each point represents the change in RGM and GEM for a 3-hour period as calculated from a linear regression line fit for that evening $(n=61)$. The regression line does not include the two circled points (which we consider outliers), and the intercept was forced to zero. A regression including the outliers has a slope of -0.82 and $\mathrm{r}^{2}=0.72$.

conversion from GEM to RGM without the loss of RGM. A slope which is greater than -1 would be consistent with the loss of RGM to precipitation, deposition or other processes. A slope of greater than -1 would also be consistent with a decrease in THg mixing ratio with height even though no RGM loss had occurred. This can be seen from the following calculation using example values from MBO.

[38] On the basis of airplane measurements of vertical profiles [Banic et al., 2003] it is likely that there is only a minimal decrease in $\mathrm{THg}$ mixing ratio with height in the lower troposphere. Let $C$ be some small difference $\left(0.075 \mathrm{ng} / \mathrm{m}^{3}\right)$, and let the total mercury in an RGM enhancement event $\left(\mathrm{THg}_{e}\right)=1.5 \mathrm{ng} / \mathrm{m}^{3}$. The total mercury in the background air is then $\mathrm{THg}_{b g}=\mathrm{THg}_{e}+C$. For an RGM enhancement value $\left(\mathrm{RGM}_{e}\right)$ of $0.5 \mathrm{ng} / \mathrm{m}^{3}$, the background RGM is negligible, and we can substitute $\mathrm{THg}=$ RGM + GEM for the respective enhancement event and background air masses to obtain

$$
\text { slope }=\frac{\mathrm{RGM}_{e}-\mathrm{RGM}_{b g}}{\mathrm{GEM}_{e}-\mathrm{GEM}_{b g}}=-\frac{\mathrm{RGM}_{e}}{\mathrm{RGM}_{e}+C}
$$

which gives a slope of -0.87 even if no RGM was lost from the air mass.

[39] For the $\Delta[\mathrm{GEM}]$ versus $\Delta[\mathrm{RGM}]$ composite, enhancement periods were selected by identifying nights with RGM values of $>50 \mathrm{pg} / \mathrm{m}^{3}$ for two or more time periods (26 nights total). A least squares regression of RGM versus GEM was fitted for each of these nights. Nineteen of the 26 nights produced a good fit $\left(\mathrm{r}^{2}>0.56\right)$. The $\Delta$ values for RGM (GEM) were then calculated by subtracting the minimum (maximum) of the best fit line for the respective night. The composited $\Delta$ values are shown in Figure 7 and include two points we consider outliers. These points are the only two periods in the campaign when RGM was detected (at $>50 \mathrm{pg} / \mathrm{m}^{3}$ ) during cloudy or intermittently cloudy conditions. Their low $\Delta[\mathrm{GEM}]: \Delta[\mathrm{RGM}]$ ratio is consistent with the deposition of RGM to the surface or lost to cloud droplets or cloud ice which would be larger than could be quantitatively sampled by our inlet. With these points removed, the correlation coefficient $\left(\mathrm{r}^{2}\right)$ with the intercept forced to zero is 0.80 with a slope of -0.89 . ( $n=61$ threehour means, which is $12 \%$ of all data, $71 \%$ of all time periods with $\mathrm{RGM}>50 \mathrm{pg} / \mathrm{m}^{3}$ and includes every value $>135 \mathrm{pg} / \mathrm{m}^{3}$.)

[40] The inverse correlation of GEM and RGM with a slope near unity shows that during these RGM enhancements, the sum of $\mathrm{Hg}$ species is approximately conserved. This argues that the RGM observed was produced by an in situ conversion and was largely preserved in the air mass. The regression slope being somewhat greater than -1 is not unexpected considering the effect of a small vertical gradient in $\mathrm{THg}$ mixing ratio and that some RGM can be expected to partition to particles (PHg) (which, during the highest RGM quartile is only about $4 \%$ of the RGM) and could be lost because of scavenging by clouds and precipitation.

\subsection{Model Results}

[41] Figure 8 shows a vertical profile of the GEOSChem-modeled RGM mean concentration and standard deviation in the MBO grid box for May-August 2005. The mean measured RGM concentration $\left(66 \mathrm{pg} / \mathrm{m}^{3}\right)$ for the nighttime is in good agreement with the modeled value $\left(52 \mathrm{pg} / \mathrm{m}^{3}\right)$, and the daytime and nighttime means are consistent with the positive vertical gradient of RGM and the general pattern of subsiding free tropospheric air at night and a boundary layer influence during the day. A composite of $\Delta[\mathrm{GEM}]$ versus $\Delta[\mathrm{RGM}]$ (see Section 3.5) was also done with the GEOS-Chem-modeled data, and produced a slope of -0.73 with $r^{2}=0.80(n=353$ hourly means which is $33 \%$ of nighttime data and $12 \%$ of all data).

[42] The modeled mean diurnal RGM pattern, plotted in Figure 4, is consistent with the observed diurnal pattern. The daytime low and nighttime peak in the modeled RGM are due primarily to meteorological factors as chemical production is insufficient. During the night, there is no $\mathrm{OH}$ production and oxidation by ozone alone would be too slow to produce the modeled increase in RGM.

[43] The peak in modeled RGM occurs slightly later than in the measurements, but this could be due to upslope flow, or to convective growth of the boundary layer which would bring low-RGM boundary layer air to the summit elevation and would not be reproduced by the modeled meteorology. Both of these factors are driven by local solar time, but the boundary layer growth would be shifted as compared to the observations because of Mount Bachelor's location on the eastern edge of the modeled grid box.

[44] A time series of the modeled and measured RGM concentrations at MBO is shown in Figure 9. This plot depicts only about three weeks of data and includes several of the largest RGM enhancement events observed at MBO during the summer. The general diurnal pattern is represented by the model, but it does not reproduce the magnitude of the largest events. Note that the during the largest observed RGM values (days 221-224), the RGM discrep- 


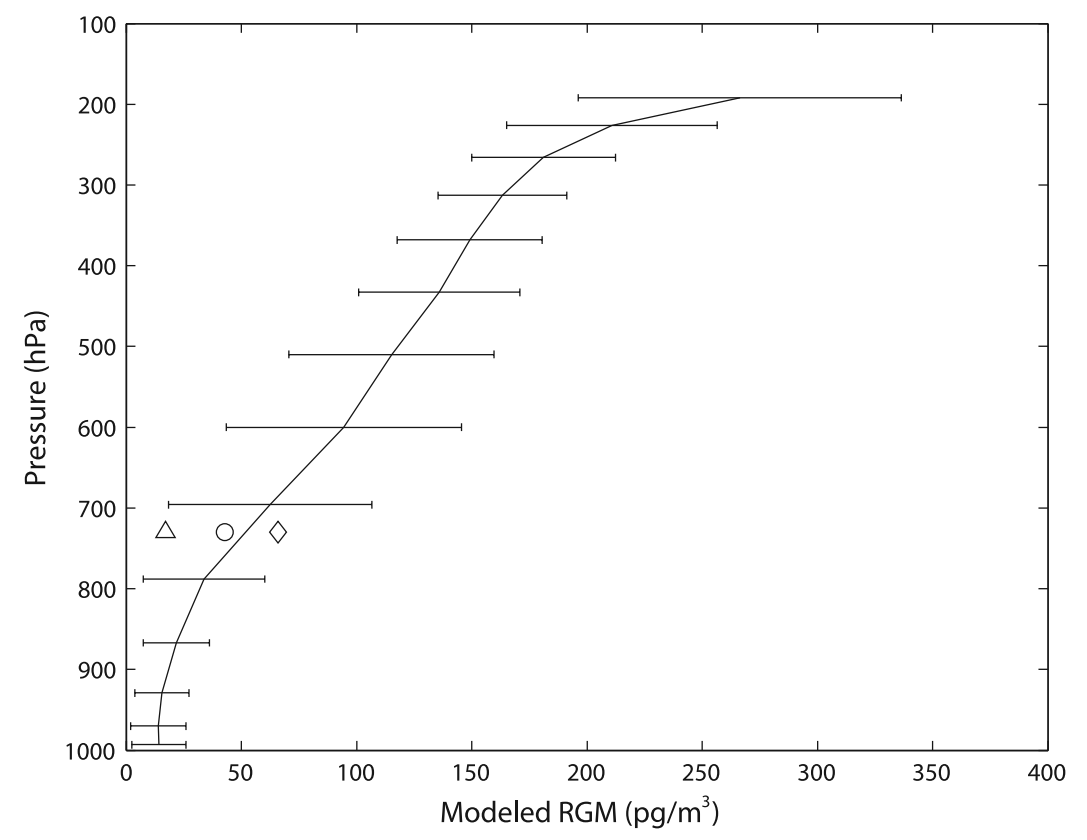

Figure 8. GEOS-Chem-modeled vertical profile of mean RGM with standard deviation $( \pm 1 \sigma)$ in the MBO grid box for the summer of 2005. The observed mean values are as follows: daytime, triangle; all times, circle; nighttime, diamond.

ancy cannot be accounted for by $\mathrm{PHg}$ as the modeled $\mathrm{PHg}$ values did not exceed $4 \mathrm{pg} / \mathrm{m}^{3}$.

[45] The GEOS-Chem model reproduces the mean RGM concentrations and diurnal pattern at MBO for the summer of 2005. It also predicts a strong increase in the RGM mixing ratio with height, which is consistent with our observation of RGM-rich air masses as subsiding from higher altitudes. Despite this agreement, the model does not reproduce the magnitude of the largest enhancements observed at MBO. We suggest three possible explanations for this discrepancy: (1) Subgrid-scale or synoptic phenomena such as stratospheric intrusions exist that are not represented well by the modeled meteorology. (2) The oxidation of GEM to RGM in the atmosphere occurs through faster or additional mechanisms than are used in the current modeled chemistry. (3) There is a positive artifact in the RGM measurement method.

[46] Explanation 1 is difficult to constrain on the basis of the ancillary data that have been collected. An examination of the modeled values of $\mathrm{CO}$, ozone, and water vapor is

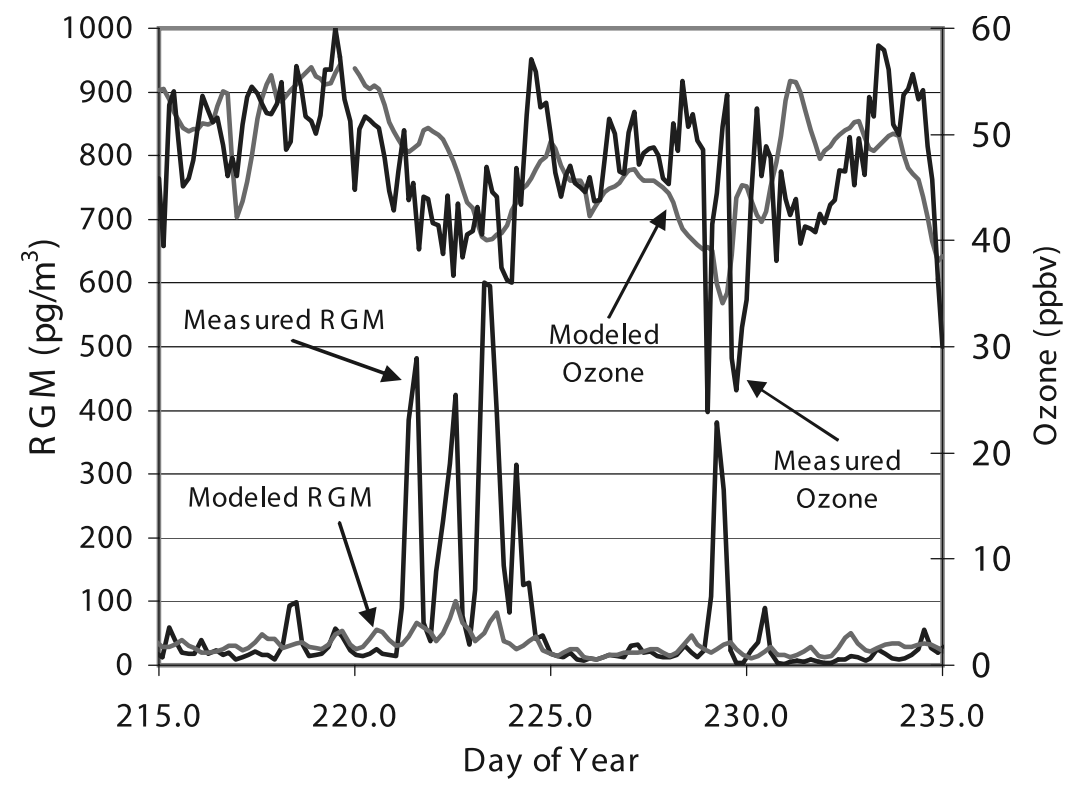

Figure 9. Time series of GEOS-Chem-predicted RGM and ozone concentrations along with measured values. Measured values are darker lines, and modeled values are lighter lines. 
inconclusive. For the 4-day period which includes the largest RGM enhancement (Figure 9), the modeled CO reproduces a strong diurnal pattern and shows good agreement $(r=0.70)$ with observations. For the same period, however, ozone and water vapor do not agree as well with $\mathrm{r}=0.45$ and 0.42 respectively. Hudman et al. [2004] discuss a model versus measurement discrepancy for ozone in which the timing of tropopause folds are well represented, but the magnitude of the chemical enhancements are not. This could also be true for mercury as the model predicts that mercury near the tropopause is predominantly in the form of RGM [Selin et al., 2006]. The weak correlation between the observed ozone and RGM along with several instances of very high RGM with little or no increase in ozone, however, argues that this explanation alone is not sufficient.

[47] Explanation 2 cannot be disregarded because of the uncertainties in our understanding of the reaction rates of known oxidation pathways [Calvert and Lindberg, 2005; Goodsite et al., 2004] and the potential existence of additional oxidation mechanisms in the free troposphere. For example, it has been suggested that $\mathrm{BrO}$ may be ubiquitous at ppt levels in the free troposphere [Fitzenberger et al., 2000; Platt and Hönninger, 2003]. Even at 1 ppt, the oxidation rates of Goodsite et al. [2004] or Ariya et al. [2002] would produce RGM many times faster than by the assumed $\mathrm{OH}$ or ozone rates. This could easily produce the levels of RGM observed in this study, however, rapid oxidation by halogens would also likely require a reduction mechanism to maintain realistic GEM mixing ratios. Also, Murphy et al. [2006] have suggested that in the lower stratosphere, bromine or iodine may be involved with the conversion of gas phase mercury to the particulate phase and that volatilization may occur as the particles descend and warm. To date there have been no measurements at MBO which could provide evidence for or against the presence of reactive halogen species.

[48] Explanation 3 must also be considered for logical completeness. While it is clear that the RGM method is quantitative for $\mathrm{HgCl}_{2}$ [Landis et al., 2002], the sensitivity of this method to other $\mathrm{Hg}$ compounds and artifacts has not been reported in the literature. Lynam and Keeler [2005] have suggested that there may be a positive artifact in which $\mathrm{RGM}$ is produced on the $\mathrm{KCl}$ surface under certain conditions.

[49] We suggest that although explanation 1 is almost certainly contributing to the observed discrepancy, it is not the dominating factor. Also, a positive method artifact cannot be eliminated a priori, but considering the method has performed well in extreme conditions [Lindberg et al., 2002; Steffen et al., 2002; Berg et al., 2003; Ebinghaus et al., 2002; Sprovieri et al., 2002; Temme et al., 2003] a significant positive artifact seems unlikely. We believe that an additional oxidation mechanism is the most likely explanation, although we cannot eliminate other possibilities.

\section{Conclusions}

[50] We measured the ambient mercury speciation at the Mount Bachelor Observatory on a continuous basis during the summer of 2005. During the night, when the air is representative of the free troposphere, the mean RGM concentration was $66 \mathrm{pg} / \mathrm{m}^{3}$. Ten percent of the nighttime sample periods had concentrations in excess of $160 \mathrm{pg} / \mathrm{m}^{3}$ with a maximum of $600 \mathrm{pg} / \mathrm{m}^{3}$. RGM enhancements were correlated with a free tropospheric principal component which is characterized by higher ozone, and lower water vapor, GEM, and CO. During RGM enhancements, $\mathrm{PHg}$ enhancements averaged only $4.1 \%$ relative to the RGM and were not correlated to the RGM. This suggests that in the observed air masses, deposition of RGM to the particles is slow relative to the oxidation rate.

[51] On the basis of the Pearson's correlation, PCA, high/ low RGM composites, and back trajectories, the RGM observed at MBO could not be directly linked to recent ( $<10$ days) anthropogenic emissions from either local sources or long-range transport. Instead, a composite of $\triangle \mathrm{RGM}$ versus $\triangle$ GEM indicates that RGM enhancements are inversely correlated to GEM with a slope near unity. This supports an in situ conversion of GEM as the source of the RGM. At MBO, the GEOS-Chem model reproduces the mean concentrations and diurnal pattern of RGM. The model is also consistent with the inverse relationship between RGM and GEM observed at MBO. This suggests that the oxidation of GEM to RGM at the rate of $\mathrm{OH}$ and ozone is sufficient to reproduce the mean observed RGM concentrations. The model, however, does not reproduce the magnitude of the enhancements observed at MBO. The possible explanations include (1) resolution of modeled meteorology, (2) additional oxidation mechanisms or faster oxidation rates, or (3) a positive method artifact. It seems likely that meteorological resolution and method artifact issues alone cannot explain the discrepancy. This suggests that there may be additional RGM production mechanisms in the free troposphere other than oxidation by ozone or $\mathrm{OH}$ or that their oxidation rates may be faster.

[52] Acknowledgments. Funding for this work was provided by an EPA STAR grant (R-82979701). It has not been subjected to any EPA review and does not necessarily reflect the view of the agency. This work would not have been possible without the cooperation and support of Mount Bachelor Ski, Inc., and their Lift Maintenance Department. Also, Carol Higgenbothen and Paul Hutter from Central Oregon Community College and Toby Primbs from Oregon State University provided valuable local support. P. Swartzendruber also wishes to acknowledge helpful discussions with Dennis Hartmann on the subtleties of principal component analysis and helpful comments from the anonymous reviewers.

\section{References}

Ariya, P. A., A. Khalizov, and A. Gidas (2002), Reactions of gaseous mercury atomic and molecular halogens: Kinetics, product studies, and atmospheric implications, J. Phys. Chem. A, 106, 7310-7320.

Banic, C. M., S. T. Beauchamp, R. J. Tordon, W. H. Schroeder, A. Steffen, K. A. Anlauf, and H. K. T. Wong (2003), Vertical distribution of gaseous elemental mercury in Canada, J. Geophys. Res., 108(D9), 4264, doi:10.1029/2002JD002116.

Berg, T., S. Sekkester, E. Steinnes, A.-K. Valdal, and G. Wibetoe (2003), Springtime depletion of mercury in the European Arctic as observed at Svalbard, Sci. Total Environ., 304, 43-51.

Bergan, T., and H. Rodhe (2001), Oxidation of elemental mercury in the atmosphere: Constraint imposed by global scale modeling, J. Atmos. Chem., 40, 192-212.

Bey, I., D. J. Jacob, R. M. Yantosca, J. A. Logan, B. Field, A. M. Fiore, Q. Li, H. Liu, L. J. Mickley, and M. Schultz (2001), Global modeling of tropospheric chemistry with assimilated meteorology: Model description and evaluation, J. Geophys. Res., 106, 23,073-23,096.

Bretherton, C. S., M. Widmann, V. P. Dymnikov, J. M. Wallace, and I. Blade (1999), The effective number of spatial degrees of freedom of a time-varying field, J. Clim., 12, 1990-2009.

Brosset, C. (1987), The behavior of mercury in the physical environment, Water Air Soil Pollut., 34, 145-166. 
Calvert, J. G., and S. E. Lindberg (2005), Mechanisms of mercury removal by $\mathrm{O}_{3}$ and $\mathrm{OH}$ in the atmosphere, Atmos. Environ., 39, 33553367.

Carpi, A. (1997), Mercury from combustion sources: A review of the chemical species emitted and their transport in the atmopshere, Water Air Soil Pollut., 98, 241-254.

Ebinghaus, R., and F. Slemr (2000), Aircraft measurements of atmospheric mercury over southern and eastern Germany, Atmos. Environ., 34, $895-$ 903.

Ebinghaus, R., et al. (1999), International field intercomparison measurements of atmospheric mercury species at Mace Head, Ireland, Atmos. Environ., 33, 3063-3073.

Ebinghaus, R., H. H. Koch, C. Temme, J. W. Einax, A. Lve, A. Richter, J. P. Burrows, and W. H. Schroeder (2002), Antarctic springtime depletion of atmospheric mercury, Environ. Sci. Technol., 36, 12381244.

Fitzenberger, R., H. Bösch, C. Camy-Peyret, M. P. Chipperfield, H. Harder, U. Platt, B.-M. Sinnhuber, T. Wagner, and K. Pfeilsticker (2000), First profile measurements of tropospheric BrO, Geophys. Res. Lett., 27(18), $2921-2924$

Friedli, H. R., L. F. Radke, R. Prescott, P. Li, J.-H. Woo, and G. R. Carmichael (2004), Mercury in the atmosphere around Japan, Korea, and China as observed during the 2001 ACE-Asia field campaign: Measurements, distributions, sources, and implications, J. Geophys. Res., 109, D19S25, doi:10.1029/2003JD004244

Goldstein, A. H., D. B. Millet, M. McKay, L. Jaegle, L. Horowitz, O. Cooper, R. Hudman, D. J. Jacob, S. Oltmans, and A. Clark (2004), Impact of Asian emissions on observations at Trinidad Head, California, during ITCT 2K2, J. Geophys. Res., 109, D23S17, doi:10.1029/ 2003JD004406.

Goodsite, M. E., J. M. C. Plane, and H. Skov (2004), A theoretical study of the oxidation of $\mathrm{Hg}^{0}$ to $\mathrm{HgBr}_{2}$ in the troposphere, Environ. Sci. Technol., $38,1772-1776$

Gustin, M., S. E. Lindberg, K. Austin, M. Coolbaugh, A. Vette, and H. Zhang (2000), Assessing the contribution of natural sources to regional atmospheric budgets, Sci. Total Environ., 259, 61-71.

Hall, B. (1995), The gas-phase oxidation of elemental mercury by ozone, Water Air Soil Pollut., 80, 301-315.

Heald, C. L., D. J. Jacob, R. J. Park, B. Alexander, T. D. Fairlie, R. M. Yantosca, and D. A. Chu (2006), Transpacific transport of Asian anthropogenic aerosols and its impact on surface air quality in the United States, J. Geophys. Res., 111, D14310, doi:10.1029/2005JD006847.

Hedgecock, I., N. Pirrone, F. Sprovieri, and E. Pesenti (2003), Reactive gaseous mercury in the marine boundary layer: Modeling and experimental evidence of its formation in the Mediterranean region, Atmos. Environ., 37, suppl. 1, S41-S49, doi:10.1016/S1352-2310(03)00236-X.

Hudman, R. C., et al. (2004), Ozone production in transpacific Asian pollution plumes and implications for ozone air quality in California, J. Geophys. Res., 109, D23S10, doi:10.1029/2004JD004974.

Jaeglé, L., D. A. Jaffe, H. U. Price, P. Weiss-Penzias, P. I. Palmer, M. J. Evans, D. J. Jacob, and I. Bey (2003), Sources and budgets for CO and $\mathrm{O}_{3}$ in the northeastern Pacific during the spring of 2001: Results from the PHOBEA-II experiment, J. Geophys. Res., 108(D20), 8802, doi:10.1029/ 2002JD003121.

Jaffe, D., E. Prestbo, P. Swartzendruber, P. Weiss-Penzias, S. Kato, A. Takami, S. Hatakeyama, and Y. Kajii (2005), Export of atmopsheric mercury from Asia, Atmos. Environ., 39, 3029-3038, doi:10.1016/ j.atmosenv.2005.01.30.

Kvietkus, K. (1995), Investigation of the gaseous and particulate mercury concentrations along horizontal and vertical profiles in the lower troposphere, in Proceedings of the 10th World Clean Air Congress, vol. 2, Atmospheric Pollution, edited by P. Anttiba, J. Kamari, and M. Jolvanen, pp. 284-287, Finn. Air Pollut. Prev. Soc., Helsinki.

Landis, M. S., R. K. Stevens, F. Schaedlich, and E. M. Prestbo (2002), Development and characterization of an annular denuder methodology for the measurement of divalent inorganic reactive mercury in the amibent air, Environ. Sci. Technol., 36, 3000-3009.

Landis, M. S., M. Lynam, and R. K. Stevens (2005), The monitoring and modeling of mercury species in support of local, regional, and global modeliing, in Dynamics of Mercury Pollution on Regional and Global Scales, edited by N. Pirrone and K. R. Mahaffy, Springer, New York.

Laurier, F. J. G., R. P. Mason, L. Whalin, and S. Kato (2003), Reactive gaseous mercury formation in the North Pacific Ocean's marine boundary layer: A potential role of halogen chemistry, J. Geophys. Res., 108(D17), 4529, doi:10.1029/2003JD003625.

Leith, C. E. (1973), The standard error of time-averaged estimates of climatic means, J. Appl. Meteorol., 12, 1066-1069.

Liang, Q., L. Jaeglé, D. A. Jaffe, P. Weiss-Penzias, A. Heckman, and J. A. Snow (2004), Long-range transport of Asian pollution to the northeast Pacific: Seasonal variations and transport pathways of carbon monoxide, J. Geophys. Res., 109(D23), D23S07, doi:10.1029/ 2003JD004402

Lindberg, S. E., and W. J. Stratton (1998), Atmospheric mercury speciation: Concentrations and behavior of reactive gaseous mercury in ambient air, Environ. Sci. Technol., 32, 49-57.

Lindberg, S., S. Brooks, C. J. Lin, K. J. Scott, M. S. Landis, R. V. Stevens, M. Goodsite, and A. Richter (2002), The dynamic oxidation of gaseous mercury in the Arctic atmosphere at polar sunrise, Environ. Sci. Technol. $36,1245-1256$

Lynam, M., and G. J. Keeler (2005), Artifacts associated with the measurement of particulate mercury in an urban environment: The influence of elevated ozone concentrations, Atmos. Environ., 39, 3081-3088.

Malcolm, E. G., G. J. Keeler, and M. S. Landis (2003), The effects of the coastal environment on the atmospheric mercury cycle, J. Geophys. Res., 108(D12), 4357, doi:10.1029/2002JD003084.

Mason, R. P., and G. R. Sheu (2002), Role of the ocean in the global mercury cycle, Global Biogeochem. Cycles, 16(4), 1093, doi:10.1029/ 2001GB001440.

Murphy, D. M., P. K. Hudson, D. S. Thomson, P. J. Sheridan, and J. C. Wilson (2006), Observations of mercury containing aerosols, Environ. Sci. Technol., 40, 3163-3167.

North, G. R., T. L. Bell, R. F. Cahalan, and F. J. Moeng (1982), Sampling errors in the estimation of empirical orthogonal functions, Mon. Weather Rev., 110, 699-706.

Pacyna, E. G., J. M. Pacyna, F. Steenhuisen, and S. Wilson (2006), Global anthropogenic mercury emission inventory for 2000, Atmos. Environ., 40, $4048-4063$

Platt, U., and G. Hönninger (2003), The role of halogen species in the troposphere, Chemosphere, 52, 325-338.

Poissant, L., M. Pilote, C. Beauvais, P. Constant, and H. H. Zhang (2005), A year of continuous measurements of three atmospheric mercury species (GEM, RGM, and Hgp) in southern Quebec, Canada, Atmos. Environ. 39, 1275-1287, doi:10.1016/j.atmosenv.2004.11.007.

Schroeder, W. H., and J. Munthe (1998), Atmospheric mercury: An overview, Atmos. Environ., 32, 809-822.

Seigneur, C., K. Vijayaraghavan, K. Lohman, P. Karamchandani, and C. Scott (2004), Global source attribution for mercury deposition in the United States, Environ. Sci. Technol., 38, 555-569.

Selin, N. E., D. Jacob, R. Park, R. M. Yantosca, S. Strode, L. Jeaglé, C. Holmes, and D. A. Jaffe (2006), Chemical cycling and deposition of atmospheric mercury: Global constraints from observations, J. Geophys. Res., doi:10.1029/2006JD007450, in press.

Sheu, G. R., and R. P. Mason (2001), An examination of methods for the measurements of reactive gaseous mercury in the atmosphere, Environ. Sci. Technol., 35, 1209-1216.

Shia, R. L., C. Seigneur, P. Pai, M. Ko, and N. D. Sze (1999), Global simulation of atmospheric mercury concentrations and deposition fluxes, J. Geophys. Res., 104, 23,747-23,760.

Sommar, J., K. Gardfeldt, D. Stromberg, and X. Feng (2001), A kinetic study of the gas-phase reaction between the hydroxyl radical and atomic mercury, Atmos. Environ., 35, 3049-3054

Sprovieri, F., N. Pirrone, I. M. Hedgecock, M. S. Landis, and R. K. Stevens (2002), Intensive atmospheric mercury measurements at Terra Nova Bay in Antarctica during November and December 2000, J. Geophys. Res., 107(D23), 4722, doi:10.1029/2002JD002057.

Sprovieri, F., N. Pirrone, K. Gardfeldt, and J. Sommar (2003), Mercury speciation in the marine boundary layer along a $6000 \mathrm{~km}$ cruise path around the Mediterranean Sea, Atmos. Environ., 37, suppl. 1, S63-S71. Steffen, A., W. Schroeder, J. Bottenheim, J. Narayan, and J. D. Fuestes (2002), Atmospheric mercury concentrations: Measurements and profiles near snow and ice surfaces in the Canadian Arctic during Alert 2000, Atmos. Environ., 36, 2653-2661.

Stratton, W. J., S. E. Lindberg, and C. J. Perry (2001), Atmospheric mercury speciation: Laboratory and field evaluation of a mist chamber method for measuring reactive gaseous mercury, Environ. Sci. Technol., 35, $170-177$.

Streets, D. G., J. Hao, Y. Wu, J. Jiang, M. Chan, H. Tian, and X. Feng (2005), Anthropogenic mercury emissions in China, Atmos. Environ., 39 $7789-7806$

Temme, C., J. W. Einax, R. Ebinghaus, and W. H. Schroeder (2003), Measurements of atmospheric mercury species at a coastal site in the Antarctic and over the South Atlantic Ocean during polar sunrise, Environ. Sci. Technol., 37, 22-31.

von Storch, H., and F. W. Zwiers (1999), Statistical Analysis in Climate Research, 484 pp., Cambridge Univ. Press, New York.

Weiss-Penzias, P., D. A. Jaffe, A. McClintick, E. M. Prestbo, and M. S. Landis (2003), Gaseous elemental mercury in the marine boundary layer: Evidence for rapid removal in anthropogenic pollution, Environ. Sci. Technol., 37, 3755-3763. 
Weiss-Penzias, P., D. A. Jaffe, P. Swartzendruber, J. B. Dennison, D. Chand, and E. M. Prestbo (2006), Observations of Asian air pollution in the free troposphere at Mount Bachelor Observatory during the spring of 2004, J. Geophys. Res., 111, D10304, doi:10.1029/2005JD006522.

D. J. Jacob, R. Park, and N. E. Selin, Department of Earth and Planetary Sciences, Harvard University, 20 Oxford Street, Cambridge MA 02138, USA.
L. Jaeglé, D. A. Jaffe, S. Strode, and P. C. Swartzendruber, Department of Atmospheric Sciences, University of Washington, ATG Building, Box 351640, Seattle, WA 98195-1640, USA. (pswartz@atmos.washington.edu) E. M. Prestbo, Frontier Geosciences, 414 Pontius Avenue N \#B, Seattle, WA 98109, USA.

P. Weiss-Penzias, Interdisciplinary Arts and Sciences, University of Washington-Bothell, Bothell, WA 98011-8246, USA. 